\title{
Neuropsychomotor development assessment of children aged 0 to 5 in early childhood public education centers
}

\author{
Luize Bueno de Araujo \\ https://orcid.org/0000-0001-9795-4043 \\ Diomar Augusto de Quadros ${ }^{2}$ \\ https://orcid.org/0000-0003-0714-4077 \\ Marília Pinto Ferreira Murata ${ }^{2}$ \\ https://orcid.org/0000-0001-5790-7525 \\ Vera Lúcia Israel ${ }^{1}$ \\ https://orcid.org/0000-0001-5824-7792
}

\section{Universidade Federal do Paraná, Curitiba Paraná, Brasil. \\ 2 Universidade Federal do Paraná, Setor Litoral, Matinhos, Paraná, Brasil.}

Project developed at the Federal University of Paraná, coastland branch campus,

Matinhos, Paraná, Brazil.

Research support source: this project was carried out with the support of the Higher Education Personnel Improvement Coordination - Brazil (CAPES, from the acronym in Portuguese) - Financing Code 001.

\section{Conflict of interests: Nonexistent}

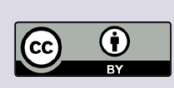

Received on: September 26, 2018 Accepted on: June 27, 2019

Corresponding address: Luize Bueno de Araujo

Avenida Cândido de Abreu, 347. Ap. 1204. Centro Cívico

CEP: 80530-000 - Curitiba, Paraná, Brasil E-mail:luizebueno@hotmail.com

\section{ABSTRACT}

Purpose: to investigate the neuropsychomotor development, as well as nutritional and cognitive/emotional aspects of children aged 0 to 5 , attending early childhood education centers, aiming at early identification and prevention of risks and delays in children's development.

Methods: the population studied was composed of 85 children attending two early childhood education centers. The children's development approach was contextual, by means of ludic physical therapy assessment, by using the DENVER II scale; complementary assessments of their nutritional status were also performed, based on anthropometric measurements of weight and height, as well as evaluations of the cognitive/ emotional development aspects through the Free Hand Drawing and Human Figure Drawing Tests.

Results: neuropsychomotor development was found to be within normal range in $69.41 \%$ of the children and questionable in $30.58 \%$ of them. The significant variable affecting the result was found to be the class in which some children were inserted. In the scale utilized, the best performance was considered to be the gross motor skills $(7.69 \%)$ and the most questionable performance occurred in the language skills (58.85\%). As for nutritional data, it was discovered that $27.06 \%$ of the children had some nutritional risk, $22.35 \%$ had obesity risk and $4.71 \%$, malnutrition risk. In the cognitive/emotional analysis, the result was that $34.37 \%$ of the children presented signs of difficulties related to adaptation and socialization or self-esteem.

Conclusion: in the present study, about one-third of the children participating presented questionable neuropsychomotor development, especially in the field of language; in this regard, the class to which the children belong may constitute a barrier to their development. These children presented nutritional risks, with a tendency towards obesity, as well as the possible difficulties regarding adaptation and socialization or self-esteem.

Keywords: Child Health Services; Early Childhood Education; Child Development; Primary Prevention 


\section{INTRODUCTION}

Motor development is considered to be a sequential, continuous and chronological-age-related process, through which humans acquire a great amount of motor skills, which progress from simple and disorganized movements to highly complex and organized motor skills'.

Therefore, human development must be understood from a broad and contextualized perspective, taking into account the dynamic interaction of people with their different contxts ${ }^{2,3}$.

The first years of the human life are essential for acquiring knowledge and skills, thus causing remarkable changes in cognitive, motor, social and affective dimensions ${ }^{4}$. Nowadays, due to socioeconomic transformations in society ${ }^{5}$, early childhood education institutions are the place where children spend most of their day in a stage fundamental for their growth and development, especially from zero to five years old. For this reason, observing child development in this stage may furnish indicators of motor development steps and their associations in order to promote health and prevent from risks and delays in neuropsychomotor development.

In the Brazilian National Education Bases and Guidelines Law (LDBEN, law number 9.394/96) care centers are defined as institutions who take care of children aged zero to three and preschoolers aged four to six. These two age groups make up the early childhood education, which is the first stage of basic education and whose purpose is the wholesome development of the child. However, Brazilian law number $11.274 / 2006^{7}$ made the combination of elementary school and middle school to last nine years, thus including six-year-old children. Therefore, children who turn six until the beginning of the school year are no longer part of the early childhood education.

It is known that, in addition to the children's biological development and the tasks given them, conditions pertaining to the environment where they grow influence aspects of their motor behavior. An environment that encourages exploration and interaction with their surroundings acts as a development facilitator. On the other hand, an environment in unfavorable conditions may slow down the pace of development and restrict the child's learning possibilities ${ }^{8}$.

Thus, scholars Amaral, Tabaquim and Lamônica ${ }^{9}$ and Barros et al. ${ }^{10}$ state that early identification of a child at risk makes possible to avoid loss in their development and minimize the damage caused by a less favorable environment for the child's development. Hence, according to Souza et al. ${ }^{11}$, it's fitting to follow the children's development in early childhood education institutions, as it enables such development's trajectory to be analyzed. In this way, children at greater risk of delay may be identified and strategies for intervention and promotion of development may be established.

Formiga, Silva and Linhares' study ${ }^{12}$ reinforce the need of the multidisciplinary team for the all-encompassing care of children and their families, especially those whose development are perceived as being at risk.

In the municipality of Matinhos (State of Paraná, Brazil), the situation of general health and education is improving and, in order to be in agreement with the concept of wholesomeness in health, it is essential to know in what condition the development of their children is, since their first years. Thereupon, this study aims at investigating the development of children aged 0 to 5 who attended two early childhood education centers in the city of Matinhos, Paraná, Brazil, aimed at the early prevention and identification of risks and delays in child development.

\section{METHODS}

This study is an exploratory, prospective, qualitative, clinical field research ${ }^{13}$ of a group of children attending early childhood education centers in the city of Matinhos, Paraná (PR), Brazil; henceforth, for brevity, these centers will be denominated ECEC1 and ECEC2. This project had the partnership of the Health Department and the Education Department of the Municipality of Matinhos, PR, since it involved its public early childhood education centers and, in the cases identified as at risk, these children were referred to the Health Department by the municipality's physical therapist in order to proceed with adequate investigation. The ludic activities ${ }^{14}$ used with DENVER II scale were contextualized as tasks in these children's school routine, with the assistance of their classroom teacher, under direct supervision of the municipality's physical therapist and with guidance from the University's professors who were involved in this project. This study was approved by the Ethics in Research Committee of the Federal University of Paraná - Science and Health Department, under Protocol number 1212.0.000.091-8.

As in all researches carried out with humans, the human beings research Resolution 466/12 of the Brazilian National Health Council (CNS - Brazil) has been respected, minimizing risks for participating 
children. The subjects' identity, as well as information about them, has been kept in secrecy. The adults responsible for the children, after due explanation about the research, filled in and signed the Informed Consent Form (ICF); these adults were free to refuse or quit participation in the study at any moment of the research, without any sort of penalty.

The selection of participants had the following inclusion criteria: children aged 0 to 5 , enrolled in one of the chosen early childhood education centers. The exclusion criteria were: children diagnosed with a disability; lack of an ICF filled in by the adult responsible for the child; absence of the child on the days when assessment took place; health factors that kept the child from participating; and, the choice of the child to either participate or not in the activities.

Firstly, the pilot study was carried out, with the intention of training the researchers in the necessary abilities. The pilot study took place in a third ECEC lest it interfere with the research data. This part of the project also had the consent of either the children's parents or the ones responsible for them, who signed the ICF. The procedure involved a time of getting acquainted with the children. Then the DENVER $\|^{15}$ motor scale was used, followed by the complementary cognitive/ emotional and nutritional assessment of one child of each age, which was the conclusion of the pilot study.

Such procedure was revised and then used at ECEC 1 and 2, where this research took place. The methodology was based on a contextual approach of the human motor development employing ludic assessment of pediatric neurological physiotherapy.

At ECEC 1 and 2, once authorized by the respective school principals, a meeting was held with the parents and/or the ones responsible for the children who studied there in order to explain the project and answer any questions. The parents were invited to fill in the ICF as well as an informative questionnaire with questions about their children to characterize them. From this moment on, the researchers began applying the project. As it had been done in the pilot study, they got acquainted with the children, the centers and its staff. Afterwards, one of the researchers worked with the motor scale, another, with the cognitive/emotional one, and the third one, with the nutritional assessment, thus, obtaining more reliable data; 85 children were evaluated in all. In the end of the evaluation, after the data had been analyzed, interventions were made with the families and with the school, as an expression of the researchers' gratitude. In that opportunity, a feedback of the findings was offered, along with necessary guidance. These interventions included inputs related to health and to the importance of stimulating areas deemed as questionable. Details concerning each child's assessments weren't alluded to, for in the cases in which the child was considered to be at risk, the municipality's physiotherapist was asked to talk with their parents and provide suitable referrals.

DENVER II Test ${ }^{15}$, a child development screening tool, was used for assessing the neuropsychomotor condition of the children, allowing the health professional to obtain parameters to judge in what stage of development the children were in at the moment they were tested. This test is for use with children aged o to 6. Their development is assessed through 125 items, grouped in four development areas, namely: Personal - Social (aspects of the child's socialization in and outside their home); Fine Motor - Adaptive (eye/hand coordination, handling of small objects); Language (utterance, ability to recognize, understand and use language); and Gross Motor (bodily motor control, as sitting and walking). The child's response is registered as: "pass", when they successfully performed the item; "fail", when they weren't successful in performing it; "no opportunity", when the child didn't have the chance to perform it; and "refusal", when they refuse to perform the item. Following that, the child is classified as having either typical or questionable motor development: "typical" when there is no delay of any kind and one item of risk at the most; and "questionable" when there are two or more items of risk and/or one or more items of delay. "Delay" means the child does not perform (or refuses to) an activity that's already performed by more than $90 \%$ of those their age; and "risk" means the child does not perform (or refuses to) two activities that's already performed by 75 to $90 \%$ of the children their age $^{15}$.

The nutritional evaluation was carried out by means of anthropometric measurements (weight and height), complying with the techniques recommended by the World Health Organization and used by the Brazilian Ministry of Health ${ }^{16}$, and was supervised by a nutritionist. The Free Hand Drawing and Human Figure Drawing Tests $^{17}$ were applied to the children aged 3 to 5 , accompanied and supervised by a psychologist, in order to evaluate the progressive aspects of their cognitive/emotional development

Statistica 7.0 and Epi Info (Version 6.0) ${ }^{18}$ were the software used for the statistical analysis. The generalized linear model test with logit connection function 
and binomial distribution was performed. The level of significance of 0.05 was adopted for the statistical tests.

\section{RESULTS}

A total of 85 children aged 0 to 5 took part in this research; of these, 34 were from 0 to 2 years old and 51 were from 2 to 5 years old. All of them were enrolled in the municipality's education system in the city of Matinhos, Paraná, Brazil, and attended ECEC 1 or 2.
In this sampling, neuropsychomotor development was found to be within normal parameters in $69.41 \%$ ( $n=59$ ) of the evaluated children, and questionable in $30.59 \%(n=26)$ of them (Figure 1). Of these, $13(50 \%)$ presented alteration in only one area of development, 11 (42.31\%) in two areas, 2 (7.69\%) in three, and none of the children presented alteration in all of the areas (Figure 2).

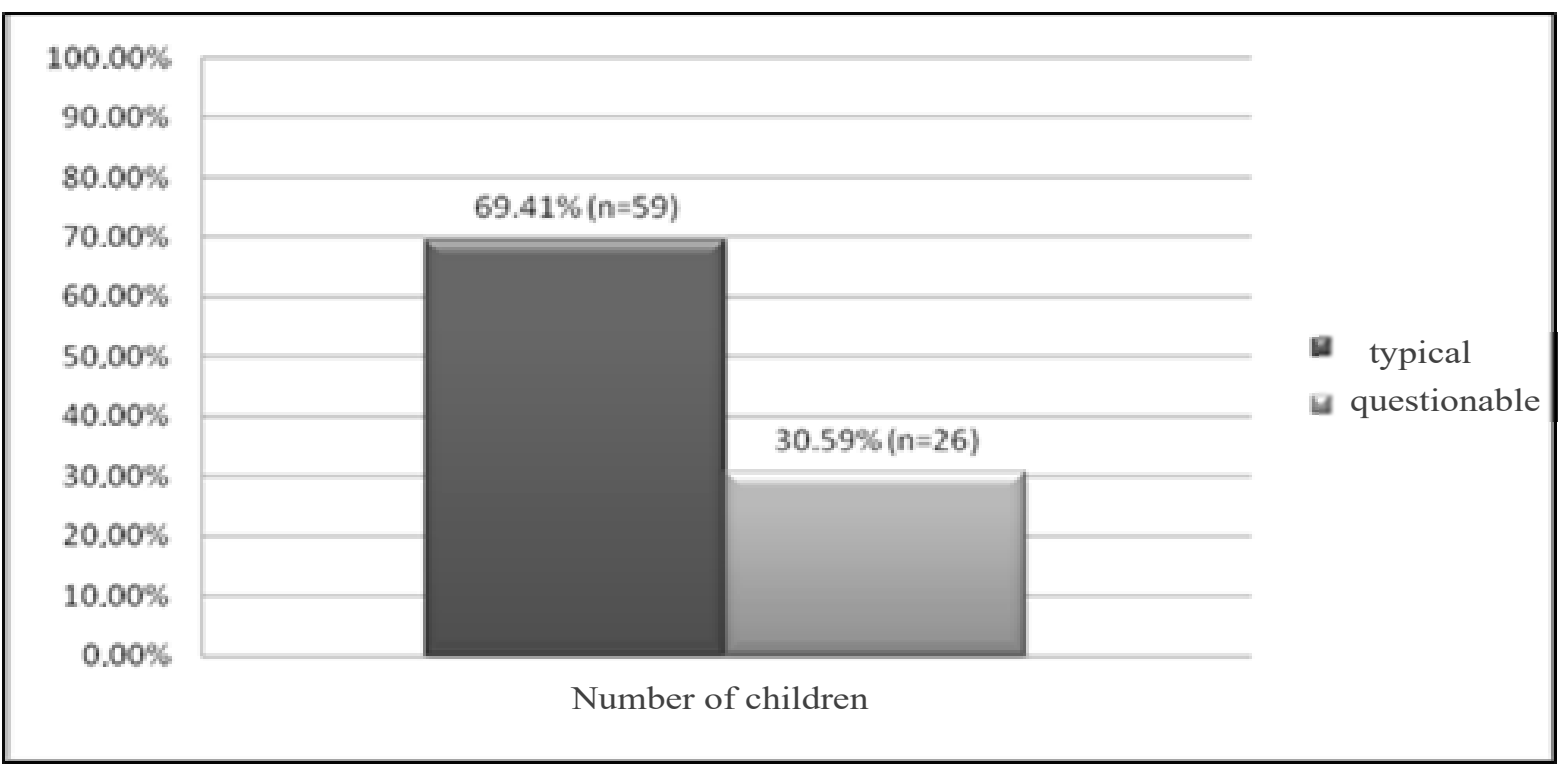

SOURCE: authors. Representation of the percentage and number of children with typical development in relation to the number of children with questionable development, according to the DENVER II Test.

Figure 1. Percentage of children with typical and questionable development

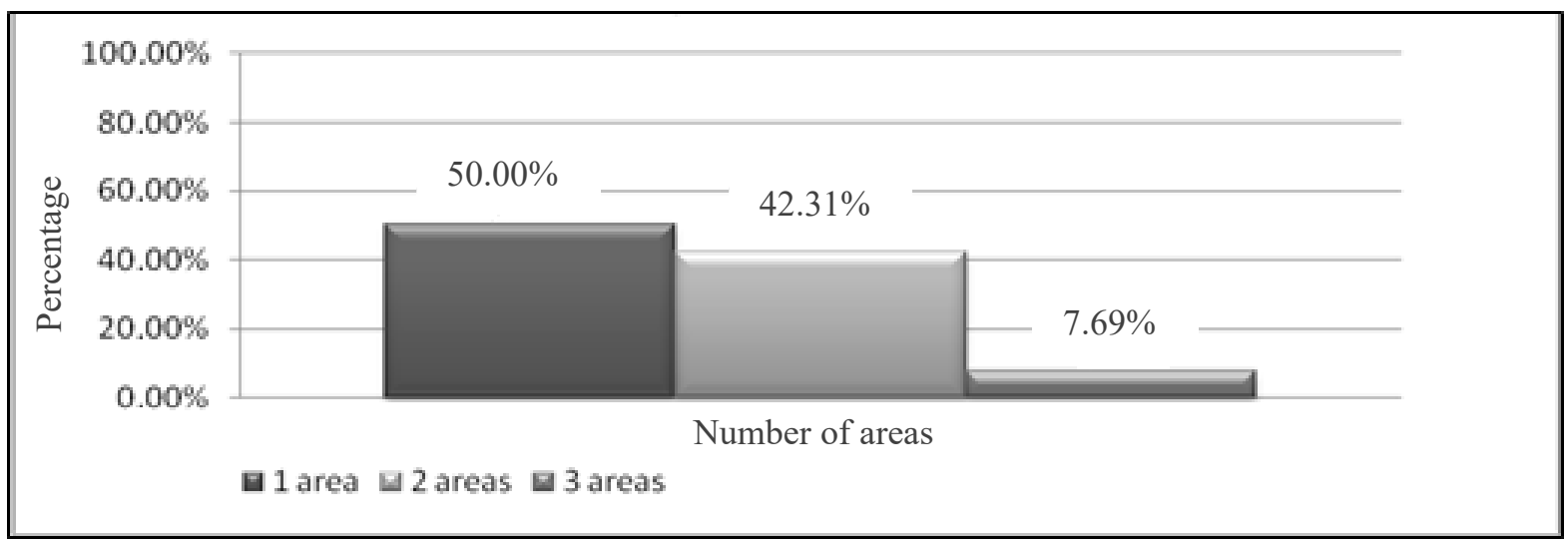

SOURCE: authors. Percentage of children with questionable development in relation to the number of affected areas.

Figure 2. Percentage of children with questionable development in one, two or three areas 
It was verified that the variable "class" was significant $(p<0.05)$ for the result, i.e., a specific class presented association with questionable neuropsychomotor development. Therefore, the children of that class were more likely to have the risk of delay in their development. Through the analysis of the sample deemed questionable, considering both the "risk" and the "delay" conditions, the area of language was verified to be the most questionable one (53.85\%), followed by fine motor - adaptive, with $21.54 \%$, then the personal - social (16.92\%), and, the least affected, the gross motor, with $7.69 \%$ (Figure 3 ).

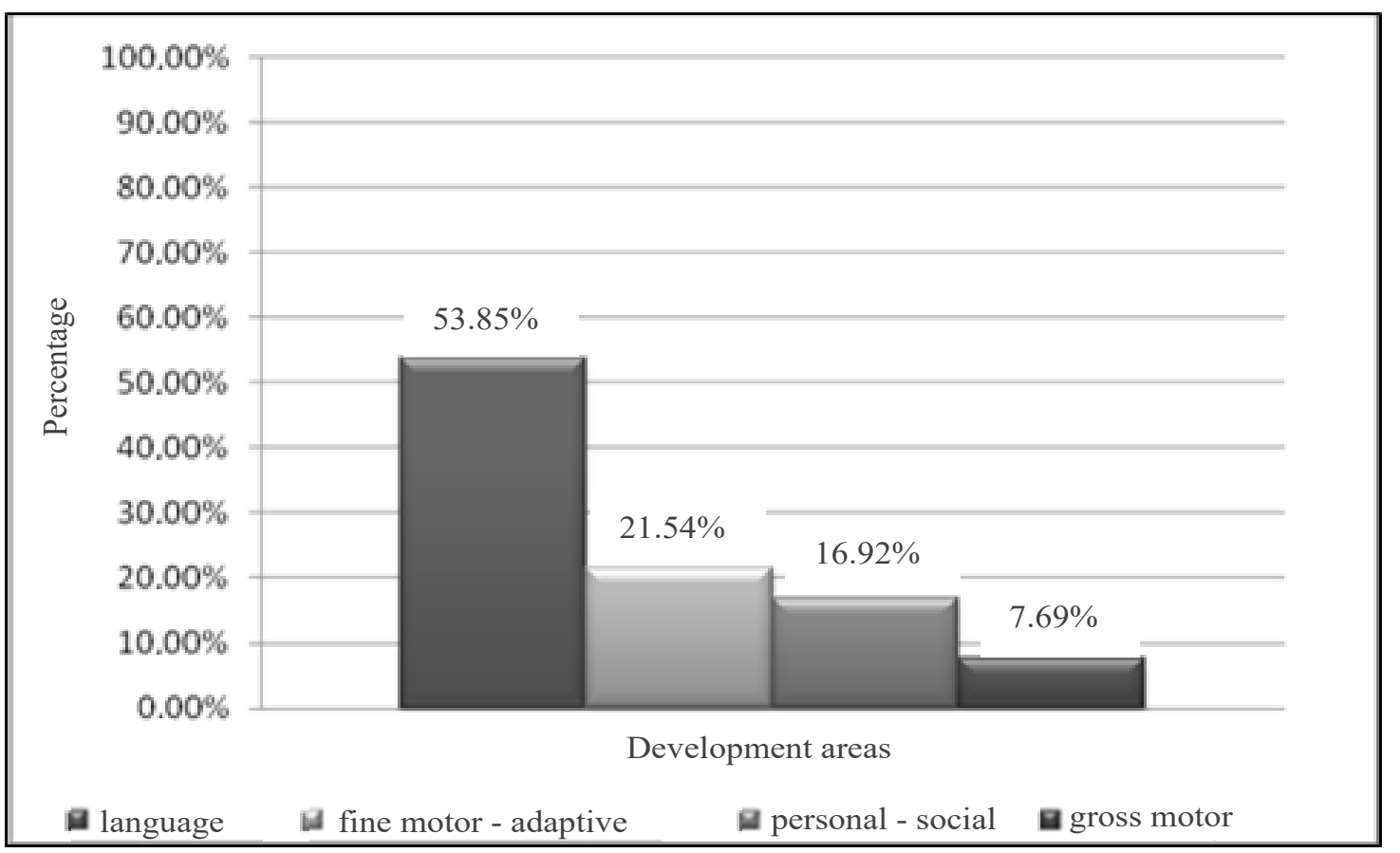

SOURCE: authors. Comparison of the affected areas in percentage.

Figure 3. Percentage of risk and delay in each area

In the nutritional evaluation, the result pointed to $27.06 \%$ of the children having some degree of nutritional risk - $22.35 \%$ at risk of obesity and $4.71 \%$ at risk of malnutrition. Considering the children who presented nutritional risk, $34.78 \%$ also had questionable neuropsychomotor development.

In the cognitive/emotional analysis, it was verified that $34.37 \%$ of the observed children presented characteristics that may indicate difficulty related to cognitive/ emotional development, which may be associated to the adaptation and socialization or self-esteem. Of these children considered to be at risk, $74.8 \%$ were assessed as having a questionable neuropsychomotor development by the DENVER II scale.

\section{DISCUSSION}

In the neuropsychomotor development analysis, performed by means of the DENVER II Test, a significant portion of the sample (30.59\%) presented questionable results. Among the evaluated aspects, language was the most affected area in this study. Brazilian studies, also carried out in early childhood education institutions, had similar results, both in the percentage of children whose development was at risk, and in the most affected area ${ }^{19,20}$.

Rezende, Costa and Pontes ${ }^{19}$ evaluated the development of 66 children in 4 public early childhood education institutions in the city of São Paulo. Through the DENVER II Test, the authors verified that $22.7 \%$ of the children presented results considered as questionable and that the area of language was the most affected of the four evaluated by the test, which was also perceived in this study. 
This study agreed with the one by Biscegli et a/20, which assessed 113 children attending a day care center in the city of Catanduva, state of São Paulo. In the neuropsychomotor development assessment through DENVER II Test, it was verified that $37 \%$ of the sampled children were suspected to be delayed in their development, and that language was the most affected area.

The research made by Costa, Cavalcante and Dell'Aglio ${ }^{21}$ verified that the suspicion of delay in language is related to the children's father's little schooling, their mother's younger age, and their lower income situation. These contextual factors have an impact on their neuropsychomotor development, and are particularly unfavorable for the linguistic development, since they may deprive them of opportunities in a stage essential to their development. In spite of these factors not being considered in this study, it's known that deficient socioeconomic conditions, parents' little schooling and teen pregnancy make part of the local reality.

Researchers ${ }^{22}$ evaluated 197 children residing in the municipality of Canoas, state of Rio Grande do Sul, $27 \%$ of whom, also assessed through DENVER II Test, were found to be under the suspicion of delay in neuropsychomotor development. However, the authors did not report which area was most affected. It did verify, though, that there were factors associated with the suspicion of delay in the children's development, namely: low family income, less than 18 months in-between their mother's pregnancies and childbirth, and their mother's lack of support from the child's father. These items were not considered in this study, although the coastal area of Paraná is known to have similar conditions. This highlights the need for developing further studies to verify the actual influence of these factors in the development of the evaluated children.

This study found that the variable associated with the questionable development was a class in which some of the children were enrolled. However, no studies were found that verified the association of the child's class with the risk in their development. It is known that the teachers' schooling and the number of children in each class may be influential factors to child development ${ }^{19}$; nonetheless, the routine of this particular class would need to be further observed in order to evaluate which factors did influence the development of these children.

In literature ${ }^{21}$, there are aspects related to delay in neuropsychomotor development, especially in the language of children enrolled in education institutions whose educators have less schooling, lower socioeconomic level, and poorer and simpler linguistic styles, in addition to an inadequate educator-child proportion and lack of training and continuous education of the professionals. These variables may be related to the particular class referred to in this study, deserving future studies for further investigation and verification.

In this study's nutritional condition assessment, there was higher prevalence of obesity $(22.35 \%)$ in comparison to malnutrition $(4.71 \%)$, similar result to that observed in the study by Biscegli et al. ${ }^{20}$. This result is in agreement with the ongoing process of nutritional transition, in which there is a decrease in the prevalence of nutritional deficits and a more expressive occurrence of obesity ${ }^{23}$.

Nutritional control is made necessary due to the high prevalence of nutritional alterations, such as malnutrition and, more recently, obesity - particularly in the period extending from birth to five years of age, when new kinds of food are being introduced in the child's diet ${ }^{20}$. These first years of life make part of a stage that is essential and at the same time vulnerable for the development and growth of the child ${ }^{24}$. Thus, the nutritional condition is related to the neuropsychomotor development, as observed in this study, which, despite the lack of a significant result, considering the children that presented some nutritional risk, $34.78 \%$ also had questionable neuropsychomotor development.

The results present in the article written by Andrade et al. ${ }^{25}$ indicated that the better the quality of the environmental stimulation available to the child, the better their cognitive performance. This relation between neuropsychomotor development and cognitive performance, also found in this study, shows the need of stimulating the aspects found to be at risk, such as socialization and social integration.

The study authored by Lordelo et al. ${ }^{26}$ evaluated the effects of a day care center in the cognitive development of children. It compared children who stayed home with those who attended the day care center and verified that attending the day care center did not influence the cognitive performance; however, it did show an association with family income and the mother's schooling. This study did not investigate family income nor the mother's schooling, therefore further investigation of the family context of the evaluated children is made necessary in order to verify the influence of family factors in their cognitive development. 
The general results of this research are in agreement with other studies ${ }^{9,10,27}$ that emphasize the need of preventive and intervening actions related to the neuropsychomotor development, with a wider health perspective, including in the school environment, aiming at furnishing an overall development of the children that spend a great part of the day in the early childhood education centers. In addition, there's a need to look attentively into language, and biological and environmental risk factors related to this area ${ }^{28}$ so as to implement stimulation and follow-up programs ${ }^{21}$ with the use of complementary tools ${ }^{29}$.

After analyzing the children's neuropsychomotor development, there's a need to deepen the investigation of the results deemed questionable in order to minimize the risk of delay in the participating children's motor and psychomotor development. It is also known that it's necessary to follow up these children for a longer period of time, with repeated evaluations.

Another issue is the establishing of early intervention and attention-giving programs, in order to have an adequate stimulation of child development since the primary prevention level. Neuropsychomotor intervention in the first months of life should not be restricted to offering stimuli and carrying out activities aimed at developing a single area; instead, the overall development of the child should be in view, with greater emphasis on the most jeopardized areas and skills.

It should be considered that cultural differences may affect these results, as well as the family's socioeconomic situation. In addition to that, it's highlighted that the screening tests call attention to a potential risk which may or may not be confirmed by means of a systematic follow-up and repeated evaluations, complemented by diagnostic tests. Nevertheless, the study suggests that children subject to potential developmental delays must be early identified, so that intervention programs mays be established aimed at preventing alterations in their development, thus offering these children at risk a set of facilitating actions for their adequate maturation in all aspects, and allowing them to reach maximum level of social integration and personal development.

Future studies are suggested, such that may define the proportion to which families and institutions influence the child development. Nonetheless, supervising the development is an important health procedure and should be undertaken regardless of the environment where the child lives. It's known that very few early childhood education institutions systematically follow up their children's development; notwithstanding, this study points out that this multidisciplinary team health procedure is made necessary.

\section{CONCLUSION}

In this research, $30.58 \%$ of the participating children presented questionable neuropsychomotor development, especially in the area of language. It was further perceived that the class in which the child is enrolled may constitute a barrier for their development. These children presented nutritional risks, with a tendency to obesity, as well as indications of difficulties related to adaptation and socialization or self-esteem.

Such findings justify actions to be taken to promote the early identification and intervention of children in these conditions. Such procedure should involve a multidisciplinary team and be active in the early childhood education institutions, since the overall development of the child should be kept in mind. The multidisciplinary team is essential for the children's development, since its evaluation must include a broad perspective about the child, encompassing the cognitive, emotional, nutritional and speech-language pathology aspects associated with the neuropsychomotor development.

\section{REFERENCES}

1. Formiga CKMR, Linhares MBM. Motor development curve from 0 to 12 months in infants born preterm. Acta Paediatr [Internet]. 2011 [cited 2018 Sep 26];100(3):379-84. Available from: https://onlinelibrary.wiley.com/doi/abs/10.1111/ j.1651-2227.2010.02002.x. http://doi.wiley. com/10.1111/j.1651-2227.2010.02002.x.

2. Gannotti ME, Christy JB, Heathcock JC, Kolobe THA. A Path Model for evaluating dosing parameters for children with cerebral palsy. Phys Ther [Internet]. 2014 [cited 2018 Sep 26];94(3):411-21. Available from: https://academic.oup.com/ptj/article-lookup/ doi/10.2522/ptj.20130022. https://doi.org/10.2522/ ptj.20130022.

3. Araujo LB, Melo TR, Israel VL. Low birth weight, family income and paternal absence as risk factors in neuropsychomotor development. J. Hum. Growth Dev. [Internet]. 2017 [cited 2018 Sep 26];27(3):272-80. Available from: http://www. revistas.usp.br/jhgd/article/view/124072. http:// dx.doi.org/10.7322/jhgd.124072.

4. Scola C, Bourjade M, Jover M. Social interaction is associated with changes in infants' motor 
activity. Socioaffective Neurosci Psychol [Internet]. 2015 [cited 2018 Sep 26];5(1):28256. Available from: https://www.ncbi.nlm.nih.gov/pmc/articles/ PMC4636864/. http://doi.org/10.3402/snp. v5.28256.

5. Guimarães FAB, Di Assis C, Vieira MEB, Formiga CKMR. Evaluation of teaching materials prepared for guidance of caregivers and day care teachers on child development. J Hum Growth Dev. [Internet]. 2015 [cited 2018 Sep 26]; 25(1):27-40. Available from: http://www.revistas.usp.br/jhgd/article/ view/96764. https://doi.org/10.7322/jhgd.96764.

6. Brasil. Lei de Diretrizes e Bases da Educação Nacional. Brasília [Internet]. 2005 [cited 2018 Sep 26];6(17):53-60. Available from: http://www. planalto.gov.br/ccivil_03/leis/19394.htm.

7. Brasil. A ampliação do ensino fundamental para 9 anos. Lei no. 11.274. Brasília [Internet]. 2006 [cited 2018 Sep 26]. Available from: http://www.planalto. gov.br/ccivil_03/_Ato2004-2006/2006/Lei/L11274. $\mathrm{htm}$.

8. Silva PL, Santos DCC, Gonçalves VMG. Influência de práticas maternas no desenvolvimento motor de lactentes do 60 ao $12^{\circ}$ meses de vida. Rev bras fisioter [Internet]. 2006 [cited 2018 Sep 26];10(2):225-31. Available from: http://www.scielo.br/scielo. php?pid $=$ S1413-35552006000200014\&script $=$ sci_ abstract\&tlng = pt. http://dx.doi.org/10.1590/ S1413-35552006000200014.

9. Amaral ADCT, Tabaquim MDLM, Lamônica DAC. Avaliação das habilidades cognitivas, da comunicação e neuromotoras de crianças com risco de alterações do desenvolvimento. Rev Bras Educ Espec [Internet]. 2005 [cited 2018 Sep 26];11(2):185-200. Available from: http://www.scielo.br/scielo.php? pid=S1413$65382005000200003 \& \mathrm{script}=\mathrm{sci}$. abstract\&tlng=pt. http://dx.doi.org/10.1590/ S1413-65382005000200003.

10. Barros KMFT, Fragoso AGC, Oliveira ALB, Cabral Filho JE, Castro RM. Do environmental influences alter motor abilities acquisition? A comparison among children from day-care centers and private schools. Arq. NeuroPsiquiatr. [Internet]. 2003 June [cited 2018 Sep 26];61(2A):170-5. Available from: http://www.scielo. $\mathrm{br} /$ scielo.php? script $=$ sci_arttext\&pid $=$ S0004282X2003000200002\&lng=en. http://dx.doi. org/10.1590/S0004-282X2003000200002.
11. Souza CT, Santos DCC, Tolocka RE, Baltieri L, Gibim NC, Habechian FAP. Assessment of global motor performance and gross and fine motor skills of infants attending day care centers. Brazilian J Phys Ther [Internet]. 2010 [cited 2018 Sep 26];14(4):309-15. Available from: http://www.scielo.br/scielo.php?script $=$ sci arttext\&pid $=$ S1413-35552010000400007\&Ing $=e$ n\&nrm=iso\&tlng=en. http://dx.doi.org/10.1590/ S0004-282X2003000200002.

12. Formiga CKMR, Silva LP, Linhares MBM. Identification of risk factors in infants participating in a Follow-up program. Rev. CEFAC [Internet]. 2018 May [cited 2018 Sep 26];20(3):333-41. Available from: http://www.scielo.br/scielo.php?script $=$ sci arttext\&pid $=$ S1516-18462018000300333\&lng =en. http://dx.doi.org/10.1590/1982-021620182038817.

13. Hochman B, Nahas FX, Oliveira Filho RS de, Ferreira LM. Desenhos de pesquisa. Acta Cir. Bras. [Internet]. 2005 [cited 2018 Sep 26];20(Suppl 2):2-9. Available from: http://www.scielo.br/ scielo. $p h p$ ?script $=$ sci_arttext \&pid $=$ S0102$86502005000800002 \& \operatorname{lng}=$ en. $\quad$ http://dx.doi. org/10.1590/S0102-86502005000800002.

14. Fujisawa DS, Manzini EJ. Formação acadêmica do fisioterapeuta: a utilização das atividades lúdicas nos atendimentos de crianças. Rev Bras Educ Espec [Internet]. 2006 [cited $2018 \mathrm{Sep}$ 26];12(1):65-84. Available from: http://www.scielo. $\mathrm{br} / \mathrm{scielo}$.php?script $=$ sci_arttext\&pid $=$ S141365382006000100006\&lng=pt\&tlng =pt. http:// dx.doi.org/10.1590/S1413-65382006000100006.

15. Frankenburg WK, Dodds JB, Archer P, Bresnick B, Maschka P, Edelman N et al. Denver II Teste de Triagem do Desenvolvimento (manual técnico). Adaptação brasileira: Sabatés AL São Paulo: Hogrefe, 2018.

16. WHO. Physical status: the use and interpretation of anthropometry. Report of a WHO Expert Committee. World Health Organization technical report series. 1995;854(1):1-452.

17. Wechsler SM, Schelini PW. Validade do desenho da figura humana para avaliação cognitiva infantil. Aval psicol. [Internet]. 2002 Jun [citado 2018 Set 26]; 1(1):29-38. Disponível em: http://pepsic.bvsalud. org/scielo.php?script $=$ sci_arttext\&pid $=$ S167704712002000100004\&lng=pt.

18. Goulart EMA. A avaliação nutricional infantil no software EPI INFO (versäo 6.0), considerando-se a 
abordagem coletiva e a individual, o grau e o tipo de desnutrição. J pediatr. 1997;73(4):225-30.

19. Rezende MA, Costa PS, Pontes PB. Triagem de desenvolvimento neuropsicomotor em instituições de educação infantil segundo o Teste de Denver II. Esc Anna Nery [Internet]. 2005 [citado 2018 Set 26];9(3):348-55. Available from: http://www.scielo. $\mathrm{br} / \mathrm{scielo}$. php? script $=$ sci_arttext\&pid $=\mathrm{S1414}$ $81452005000300003 \&$ Ing $=$ pt\&tlng $=$ pt. http:// dx.doi.org/10.1590/S1414-81452005000300003.

20. Biscegli TS, Polis LB, Santos LM, Vicentin M. Avaliação do estado nutricional e do desenvolvimento neuropsicomotor em crianças freqüentadoras de creche. Rev Paul Pediatr [Internet]. 2007 [citado 2018 Set 26];25(4):337-42. Available from: http:// www.scielo.br/scielo.php?script $=$ sci arttext\&pid $=$ S0103-05822007000400007\&lng $=e$ n\&nrm=iso\&tlng=pt. http://dx.doi.org/10.1590/ S0103-05822007000400007.

21. Costa EF, Cavalcante LIC, Dell'Aglio DD. Language development profile of children in Belem, according to Denver developmental screening test. Rev. CEFAC [Internet]. 2015 Aug [cited 2018 Sep 26];17(4):1090-102. Available from: $\quad$ http://www.scielo.br/scielo.php?script $=$ sci_ arttext\&pid $=S 1516-18462015000401090 \&$ Ing $=$ en. http://dx.doi.org/10.1590/1982-0216201517418514.

22. Pilz EML, Schermann LB. Determinantes biológicos e ambientais no desenvolvimento neuropsicomotor em uma amostra de crianças de Canoas/RS. Ciênc saúde coletiva [Internet]. 2007 Mar [cited 2018 Sep 26];12(1):181-90. Available from: http://www.scielo. $\mathrm{br} / \mathrm{scielo}$. php?script $=$ sci_arttext\&pid $=\mathrm{S1413}$ $81232007000100021 \& \operatorname{lng}=$ en. $\quad$ http://dx.doi. org/10.1590/S1413-81232007000100021.

23. Guimarães LV, Barros MBA. As diferenças de estado nutricional em pré-escolares de rede pública e a transição nutricional. $\mathrm{J}$ pediatr. 2001;77(5):381-6.

24. Willrich A, Azevedo CCF, Fernandes JO. Desenvolvimento motor na infância: influência dos fatores de risco e programas de intervenção. Rev Neurocienc. 2009;17(1):51-6.

25. Andrade SA, Santos DN, Bastos AC, Pedromônico MRM, Almeida-Filho N, Barreto ML. Ambiente familiar e desenvolvimento cognitivo infantil: uma abordagem epidemiológica. Rev Saúde Pública [Internet]. 2005 Aug [cited 2018 Sep 26];39(4): 606-11. Available from: http://www.scielo.br/ scielo. php? script $=$ sci_arttext $\&$ pid $=$ S0034$89102005000400014 \&$ lng $=$ en. $\quad$ http://dx.doi. org/10.1590/S0034-89102005000400014.

26. Lordelo EDR, Chalhub AA, Guirra RC, Carvalho CS. Context and cognitive development: attendance to day care center and evolution of mental development. Psicol Reflexão e Crítica [Internet]. 2007 [cited 2018 Sep 26];20(2):324-34. Available from: http://www.scielo.br/scielo.php?script=sci arttext\&pid=S0102-79722007000200019. http:// dx.doi.org/10.1590/S0102-79722007000200019.

27. Saccani R, Brizola E, Giordani AP, Bach S, Resende TL, Almeida CS. Avaliação do desenvolvimento neuropsicomotor em crianças de um bairro da periferia de Porto Alegre. Sci Med (Porto Alegre) [Internet]. 2007 [cited 2018 Sep 26];17(3):130-7. Available from: http://www.doaj.org/doaj?func=full text\&ald $=1156612$.

28. Zago JTC, Pinto PAF, Leite HR, Santos JN, Morais RLS. Association between neuropsychomotor development and biological and environmental risk factors in early childhood children. Rev. CEFAC [Internet]. 2017 June [cited 2018 Sep 26];19(3): 320-9. Available from: http://www.scielo. $\mathrm{br} /$ scielo.php? script $=$ sci_arttext $\&$ pid $=$ S151618462017000300320\&lng =en. http://dx.doi. org/10.1590/1982-0216201719314416.

29. Oliveira AC, César CPHAR, Matos GG, Passos PS, Pereira LD, Alves $T$ et al . Hearing, language, motor and social skills in the child development: a screening proposal. Rev. CEFAC [Internet]. 2018 Apr [cited 2018 Sep 26];20(2):218-27. Available from: http://www.scielo.br/scielo.php?script $=$ sci arttext\&pid=S1516-18462018000200218\&Ing $=$ en . http://dx.doi.org/10.1590/1982-0216201820216617. 